A. Wisneni : Keberlanjutan Pengembangan Lorong Garden dalam Mewujudkan Kawasan Perkotaan Ramah Lingkungan (Eco City) di Makassar

\title{
STRATEGI PENGELOLAAN HUTAN RAKYAT DI KABUPATEN LUWU UTARA
}

\author{
${ }^{1)}$ Salma A.Kaisang, ${ }^{2)}$ Nuraeni, ${ }^{2)}$ St. Subaedah \\ ${ }^{1)}$ Mahasiswa Program Studi Magister Agroekoteknologi \\ ${ }^{21)}$ Dosen Fakultas Pertanian Universitas Muslim Indonesia, Makassar
}

\begin{abstract}
People forest in North Luwu regency has a large enough potential but has not been managed intensively. The purpose of this research : reviewing people forest management in North Luwu regency, identifying internal and external factors in people forest management and formulate people forest management strategies in North Luwu regency.

This research was conducted in North Luwu regency with a survey method in three dictricts, the sample was taken randomly with a total of 47 respondents. Data analysis was performed using descriptive methods and SWOT analysis. The result of the analyses indicated that the strategy could be best applied was strength-opportunity (SO) strategy, namely by (1) land optimization by developing agroforestry systems to increase land productivity by planting MPTS (Multipurpose Tree Species) plants and the same time minimizing erosion, (2) increase the institutional capacity of forest farmer groups (KTH), and (3) inventory of existing potential to regulate planting and production in order to ensure the sustainability of people forest.
\end{abstract}

Kata Kunci : people forest; SWO; management strategy

\section{PENDAHULUAN}

Hutan merupakan salah satu sumberdaya alam yang semakin berkurang. Badan Pusat Statistik merilis dari tahun 2014-2018 telah terjadi penyempitan lahan hutan sebesar 2,6 juta hektare yang terjadi hampir di seluruh pulau di Indonesia yang diakibatkan karena adanya peristiwa alam, penebangan hutan dan kebakaran. Menyempitnya lahan hutan juga karena tingginya laju deforestasi yang dipengaruhi perkembangan penduduk.

Jumlah penduduk yang semakin meningkat mengakibatkan peningkatan kebutuhan akan produk yang berbahan dasar kayu yang berasal dari kayu hutan sehingga menimbulkan tekanan terhadap hutan baik secara legal maupun illegal. Peningkatan jumlah penduduk juga mengakibatkan meningkatnya permintaan konversi hutan untuk dijadikan lahan pertanian, perkebunan, pemukiman penduduk dan pembukaan jalan.

Seiring dengan semakin terasanya kekurangan hasil kayu dari kawasan hutan negara, maka perkembangan pembangunan kehutanan menuntut untuk memperhatikan dan memperhitungkan keberadaan hutan rakyat. Hutan rakyat merupakan salah satu model pengelolaan sumberdaya alam yang berdasarkan inisiatif masyarakat. Hutan rakyat dibangun secara swadaya oleh 
A. Wisneni : Keberlanjutan Pengembangan Lorong Garden dalam Mewujudkan Kawasan Perkotaan Ramah Lingkungan (Eco City) di Makassar

masyarakat, ditujukan untuk rakyat masih dilakukan secara individual menghasilkan kayu dan komoditas ikutan pada lahan miliknya, hal ini lainnya yang secara ekonomis bertujuan menggambarkan bahwa hutan rakyat tidak untuk meningkatkan pendapatan dan berada pada satu hamparan tetapi tersebar kesejahteraan masyarakat. Hal ini dapat berdasarkan letak, luas kepemilikan dan dilihat dari adanya hutan rakyat keragaman pola tanam atau pola usaha tradisional yang diusahakan masyarakat tani.

sendiri tanpa campur tangan pemerintah baik berupa tanaman sejenis maupun dengan pola tanaman campuran (Awang, 2005).

Keberadaan hutan rakyat sebagai salah satu bentuk pengelolaan hutan nasional memiliki peran yang sangat penting dan strategis. Dengan adanya program pengelolaan hutan berbasis masyarakat (community based forest management) sebagai salah satu usaha peningkatan kesejahteraan masyarakat yang hidup disekitar hutan dapat memberikan peluang besar untuk mengembangkan usaha tani hutan rakyat.

Kabupaten Luwu Utara memiliki potensi hutan rakyat yang cukup luas yaitu \pm 51.377,75 Ha (Dinas Hutbun, 2015) yang tersebar di 12 kecamatan.Hutan rakyat yang ada di Kabupaten Luwu Utara sudah berkembang sejak lama, namun pengelolaannya belum dilakukan secara intensif. Walaupun sebagian besar petani hutan rakyat telah bergabung membentuk

1. Mengkaji pengelolaan hutan rakyat di Kabupaten Luwu Utara. 2. Mengidentifikasi faktor-faktor
internal dan eksternal dalam
pengelolaan hutan rakyat di
Kabupaten Luwu Utara.
3. Merumuskan strategi pengelolaan
hutan rakyat di Kabupaten Luwu
Utara. 2. Mengidentifikasi faktor-faktor
internal dan eksternal dalam
pengelolaan hutan rakyat di
Kabupaten Luwu Utara.
3. Merumuskan strategi pengelolaan
hutan rakyat di Kabupaten Luwu
Utara. 2. Mengidentifikasi faktor-faktor
internal dan eksternal dalam
pengelolaan hutan rakyat di
Kabupaten Luwu Utara.
3. Merumuskan strategi pengelolaan
hutan rakyat di Kabupaten Luwu
Utara. 2. Mengidentifikasi faktor-faktor
internal dan eksternal dalam
pengelolaan hutan rakyat di
Kabupaten Luwu Utara.
3. Merumuskan strategi pengelolaan
hutan rakyat di Kabupaten Luwu
Utara. 2. Mengidentifikasi faktor-faktor
internal dan eksternal dalam
pengelolaan hutan rakyat di
Kabupaten Luwu Utara.
3. Merumuskan strategi pengelolaan
hutan rakyat di Kabupaten Luwu
Utara. 2. Mengidentifikasi faktor-faktor
internal dan eksternal dalam
pengelolaan hutan rakyat di
Kabupaten Luwu Utara.
3. Merumuskan strategi pengelolaan
hutan rakyat di Kabupaten Luwu
Utara. 2. Mengidentifikasi faktor-faktor
internal dan eksternal dalam
pengelolaan hutan rakyat di
Kabupaten Luwu Utara.
3. Merumuskan strategi pengelolaan
hutan rakyat di Kabupaten Luwu
Utara.

yang dilakukan belum intensif dikhawatirkan akan mempengaruhi keberlanjutan dari hutan rakyat yang ada di Kabupaten Luwu utara. Pengelolaan hutan rakyat yang diperlukan adalah pengelolaan yang berkelanjutan dan tidak bersifat sesaat. Oleh karena itu perlu dilakukan kajian mengenai strategi pengelolaan hutan rakyat di Kabupaten Luwu Utara.Tujuan penelitian ...

\section{Tujuan dari penelitian ini, yaitu :}

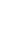


A. Wisneni : Keberlanjutan Pengembangan Lorong Garden dalam Mewujudkan Kawasan Perkotaan Ramah Lingkungan (Eco City) di Makassar

\section{METODE PENELITIAN}

\section{Lokasi dan Waktu Penelitian}

Penelitian ini dilaksanakan di Kecamatan Sabbang, Kecamatan Baebunta dan Kecamatan Masamba Kabupaten Luwu Utara atas pertimbangan bahwa daerah tersebut memiliki potensi hutan rakyat yang cukup besar. Waktu pelaksanaan penelitian ini selama 3 (tiga) bulan, yaitu bulan Februari sampai dengan bulan April 2020.

\section{Jenis dan Sumber Data}

Data yang dikumpulkan terdiri dari dua jenis yaitu data primer dan data sekunder. Data primer diperoleh dari narasumber yang dianggap relevan untuk memberikan informasi terkait pelaksanaan penelitian yaitu dari responden melalui wawancara secara langsung dengan menggunakan daftar pertanyaan (kuisioner yang telah disusun) dan dari penyuluh kehutanan lapangan. Data primer juga diperoleh melalui pengamatan langsung di lapangan khususnya terkait data pola tanam dan jenis tanaman.

Data sekunder diperoleh dari instansi terkait yang berkaitan dengan penelitian ini yaitu Badan Pusat Statistik (BPS), UPT KPH Rongkong dan sumber data lainnya terkait dengan objek penelitian. Data sekunder tersebut terrsedia dalam bentuk laporan-laporan tertulis dan dokumen lainnya.

\section{Populasi dan Sampel}

Populasi merupakan sekelompok objek yang menjadi sasaran penelitian. Populasi dalam penelitian ini adalah masyarakat yang mengelola hutan rakyat dan telah tergabung di dalam Kelompok Tani Hutan. Penentuan sampel dilakukan dengan cara acak (random sampling) dengan menentukan $10 \%$ dari jumlah populasi sehingga didapatkan 47 orang responden petani pengelola hutan rakyat.

\section{Analisis Data}

Sesuai dengan tujuan penelitian, analisis yang digunakan dalam penelitian ini adalah analisis Deskriptif untuk menggambarkan pengelolaan hutan rakyat di Kabupaten Luwu Utara dan analisis SWOT (Strength, Weakness, Opportunity,Threat) untuk merumuskan strategi pengelolaan hutan rakyat di Kabupaten Luwu Utara.

\section{HASIL DAN PEMBAHASAN}

\section{Karakteristik Responden}

Karakteristik responden diperlukan sebagai gambaran umum keadaan masyarakat yang mengelola hutan rakyat yang menjadi sampel dan merupakan obyek dalam penelitian. Karakteristik responden yang dibahas dalam penelitian 
A. Wisneni : Keberlanjutan Pengembangan Lorong Garden dalam Mewujudkan Kawasan Perkotaan Ramah Lingkungan (Eco City) di Makassar

ini, terdiri dari umur responden, tingkat tani. Hasil penelitian mengenai pendidikan, pekerjaan , jumlah karakteristik responden tersaji pada tabel tanggungan dan pengalaman berusaha berikut.

Tabel 1. Karakteristik Responden Pengelola Hutan Rakyat di Kabupaten $\quad$ Luwu Utara

\begin{tabular}{cccc}
\hline Karakteristik Individu & Jumlah (Orang) & Persentase (\%) \\
\hline \multirow{2}{*}{ Umur } & $<45$ & 12 & 25.5 \\
& $45-59$ & 29 & 61.7 \\
& $\geq 60$ & 6 & 12.8 \\
Jumlah & SD & $\mathbf{4 7}$ & $\mathbf{1 0 0}$ \\
\hline Tingkat & SMP & 19 & 40.4 \\
Pendidikan & SMA & 18 & 38.3 \\
& Jumlah & 10 & 21.3 \\
& Petani & $\mathbf{4 7}$ & $\mathbf{1 0 0}$ \\
\hline \multirow{2}{*}{ Pekerjaan } & Lainnya & 40 & 85.1 \\
& Jumlah & 7 & 14.9 \\
\hline Jumlah & $<5$ & $\mathbf{4 7}$ & $\mathbf{1 0 0}$ \\
Tanggungan & $\geq 5$ & 17 & 36.2 \\
& Jumlah & 30 & 63.8 \\
\hline Pengalaman & $<5$ & $\mathbf{4 7}$ & $\mathbf{1 0 0}$ \\
Berusahatani & $5-10$ & 2 & 4.3 \\
& $>10$ & 7 & 14.9 \\
& Jumlah & 38 & 80.9 \\
\hline
\end{tabular}

Sumber : Analisis Data Primer, 2020

Dari hasil olahan data primer diketahui bahwa umur responden secara keseluruhan berada pada selang umur antara $38-60$ tahun. Berdasarkan Tabel 1, diketahui bahwa jumlah responden yang memiliki umur kategori usia muda yaitu di bawah 45 tahun sebanyak 12 orang $(25,5 \%)$ hal ini menunjukkan bahwa masih ada minat generasi muda untuk menggeluti bidang pertanian termasuk usaha hutan rakyat. Terdapat 29 orang responden $(61,7 \%)$ berada pada kategori usia pertengahan yaitu umur 45 - 59 tahun dan 6 orang responden $(12,8$
\%) berada pada kategori lanjut usia yaitu berumur 60 tahun. Berdasarkan data tersebut menunjukkan bahwa umur responden dominan berada pada kategori 45-59 tahun $(61,7 \%)$ yang tergolong masih berada pada kategori umur produktif.

Hasil pengolahan data pada Tabel 1, menunjukkan bahwa jumlah responden yang berpendidikan SD sebanyak 19 orang $(40,4 \%)$, berpendidikan SMP sebanyak 18 orang $(38,3 \%)$ dan SMA sebanyak 10 orang (21,3\%). Gambaran tingkat pendidikan petani ini 
A. Wisneni : Keberlanjutan Pengembangan Lorong Garden dalam Mewujudkan Kawasan Perkotaan Ramah Lingkungan (Eco City) di Makassar

menunjukkan sebagian besar responden anggota keluarga dapat diketahui memiliki kemampuan membaca dan ketersediaan tenaga kerja dalam rumah menulis, sehingga memungkinkan petani tangga petani itu sendiri. Dari hasil untuk mengakses informasi dari media wawancara dan pengolahan data massa sesuai kebutuhan, namun pada diketahui jumlah anggota keluarga umumnya responden berada di pedesaan responden bervariasi dari 3 - 7 jiwa dan sehingga kemampuan mengakses sebanyak 63,8\% dari total seluruh informasi yang ada sangat rendah.

Usaha hutan rakyat memberikan responden memiliki 5 atau lebih anggota keluarga.

pendapatan tambahan bagi masyarakat di

Faktor pengalaman berusahatani Kabupaten Luwu Utara. Meskipun hutan rakyat perlu diketahui karena sebagian besar responden memiliki berpengaruh terhadap tingkat pengetahuan pekerjaan sebagai petani, namun tidak dan penguasaan ketrampilan responden menjadikan usaha hutan rakyat sebagai dalam mengelola hutan rakyat. Dari hasil pekerjaan utama. Hal ini disebabkan karena usaha hutan rakyat membutuhkan jangka waktu yang lama untuk penelitian di lapangan, lama pengalaman berusahatani hutan rakyat responden bervariasi mulai dari 4 sampai 30 tahun memperoleh hasil berupa kayu. Jumlah responden yang pekerjaan utamanya adalah petani sebanyak 40 orang $(85,1 \%)$. Masyarakat melakukan usaha hutan rakyat sebagai pekerjaan sampingan, dimana kayu dianggap sebagai "tabungan" yang pada saat diperlukan dapat ditebang (Hardjanto, 2006).

Jumlah anggota keluarga yang masih menjadi tanggungan juga penting untuk diketahui yang berhubungan terhadap konstribusi pendapatan yang diperoleh untuk kegiatan usahatani maupun untuk konsumsi rumah tangga, disamping itu dengan mengetahui jumlah berbanding lurus dengan usia responden itu sendiri.

\section{Pengelolaan Hutan Rakyat}

Pengelolaan hutan rakyat di Kabupaten Luwu Utara telah dilakukan sejak lama secara turun temurun terutama pada daerah-daerah pegunungan ataupun pada daerah yang berbatasan langsung dengan kawasan hutan Negara. Pada daerah-daerah dataran rendah maupun pesisir, hutan rakyat yang ada sebagian besar merupakan pengembangan dari program Rehabilitasi Lahan maupun Kebun Bibit Rakyat (KBR). 
A. Wisneni : Keberlanjutan Pengembangan Lorong Garden dalam Mewujudkan Kawasan Perkotaan Ramah Lingkungan (Eco City) di Makassar

Secara umum sebaran hutan rakyat lebih dominan di wilayah kecamatan yang berbatasan dengan kawasan hutan negara, wilayah ini memiliki topografi berupa pengunungan sehingga kurang produktif untuk tanaman pangan. Pengelolaan hutan rakyat yang telah dilakukan masyarakat di Kabupaten Luwu Utara berdasarkan hasil penelitian diuraikan berikut ini.

\section{Status Kepemilikan Lahan}

Status kepemilikan lahan merupakan faktor yang sangat penting bagi petani untuk menentukan bentuk penggunaan lahan. Usaha hutan rakyat memerlukan lahan sebagai modal usaha. Berdasarkan hasil wawancara diketahui bahwa $100 \%$ responden menyatakan bahwa hutan rakyat yang dikelola adalah milik sendiri.
Lahan berupa hak milik atau milik sendiri merupakan kekuatan utama untuk tetap mengusahakan hutan rakyat. Menurut Suprapto (2010) keputusan penggunaan lahan tersebut bergantung kepada pemilik lahan, lahan tersebut tetap akan dipertahankan sebagai hutan rakyat atau akan dipergunakan untuk peruntukan lain.

\section{Luas Lahan dan Pola Tanam}

Pengelolaan hutan rakyat pada umumnya dilakukan secara perorangan (individual) pada lahan miliknya sehingga tidak mengelompok tetapi tersebar berdasarkan letak, luas kepemilikan lahan dan keragaman pola tanam. Luas dan pola tanam hutan rakyat responden di lokasi penelitian disajikan pada Tabel 2.

Tabel 2. Sebaran Responden Berdasarkan Luas dan Pola Tanam pada Hutan Rakyat

\begin{tabular}{cccc}
\hline \multicolumn{2}{c}{ Karakteristik Lahan } & Jumlah (Orang) & Persentase (\%) \\
\hline \multirow{4}{*}{ Luas Hutan Rakyat } & $<0,5$ & 0 & 0.0 \\
& $0,5-1$ & 16 & 34.0 \\
& $>1$ & 31 & 66.0 \\
& Jumlah & $\mathbf{4 7}$ & $\mathbf{1 0 0}$ \\
\hline \multirow{4}{*}{ Pola Pengelolaan } & Monokultur & 8 & 17.0 \\
& Polikultur & 2 & 4.3 \\
& Agroforestry & 37 & 78.7 \\
\hline
\end{tabular}

Sumber : Analisis Data Primer, 2020

Tabel 2 tersebut menunjukkan bahwa dari 47 responden tidak terdapat responden yang mengelola hutan rakyat di bawah 0,5 ha, terdapat $34 \%$ responden yang mengelola hutan rakyat dengan luas antara $0,5-1$ ha dan sebagian besar responden mengelola hutan rakyat dengan luas lebih dari 1 ha yaitu sebanyak $66 \%$. Hal ini menggambarkan bahwa ketersediaan lahan untuk usahatani hutan rakyat di Kabupaten Luwu Utara masih cukup luas. 
A. Wisneni : Keberlanjutan Pengembangan Lorong Garden dalam Mewujudkan Kawasan Perkotaan Ramah Lingkungan (Eco City) di Makassar

Responden yang melakukan pola merupakan sistem yang cukup baik tanam sistem monokultur yaitu menanam dikembangkan untuk hutan rakyat. Pola satu jenis tanaman kehutanan sebanyak $17 \%$, jenis tanaman yang ditanam yaitu tanam ini bermanfaat secara ganda, di Jabon atau Sengon. Sebanyak 4,3\% responden melakukan penanaman sistem polikultur yaitu menanam dua atau lebih tanaman kehutanan pada lahan yang sama, jenis tanaman yang ditanam yaitu Uru, Bitti, Jabon dan Sengon. Sistem agroforestri yang mengkombinasikan antara tanaman kehutanan, pertanian dan perkebunan paling dominan dilakukan oleh responden yaitu sebanyak $78 \%$, tanaman penyusun pola tanam ini cukup beragam antara lain Uru, Bitti, Terap, Jabon, Sengon, Langolian, Kelapa, Kelapa Sawit, Kakao, Aren, Bambu, Pisang, Durian, Rambutan, Langsat, Cempedak, Jengkol, Patikala (Kecombrang), Jahe, Lengkuas, Ubi Kayu dan Cabai.

Dari data di atas terlihat bahwa luas hutan rakyat yang dikelola responden berbanding lurus dengan pola tanam yang diterapkan. Petani hutan rakyat yang mempunyai luasan lahan yang sempit cenderung mengelola hutan rakyat kearah pola tanam monokultur, sedangkan pada lahan yang luas cenderung dikelola dengan pola tanam sistem agroforestri. Menurut Hardjanto (2003), pola tanam campuran terutama agroforestri samping meningkatkan pendapatan petani juga menjaga kelestarian lingkungan (ekologi) karena pola ini berorientasi pada optimalisasi pemanfaatan lahan secara rasional baik dari aspek ekologi, ekonomi, maupun aspek sosial budaya.

\section{Penerapan Teknik Silvikultur}

Hutan rakyat yang dikelola responden sebagian besar adalah hutan rakyat yang diperoleh secara turun temurun, dimana sebagian besar pohon yang ada tumbuh secara alami ataupun ditanam dengan waktu yang tidak sama.

Hasil wawancara dengan responden diketahui bahwa penerapan teknik silvikultur tergantung pada pola tanam yang dilakukan dimana untuk pola tanam polikultur dan agroforestri hanya sebagian kecil dari teknik silvikultur yang diterapkan, pada umumnya tanaman dibiarkan tumbuh secara alami, dimana jenis tanaman dan umur tanaman beragam serta jarak tanam yang tidak teratur. Pada pola monokultur pengaturan jarak tanam dilakukan dimana sampai pada umur tertentu jarak antar baris tanaman ditanami dengan tanaman semusim seperti nilam, jagung dan cabai. Pemeliharaan 
A. Wisneni : Keberlanjutan Pengembangan Lorong Garden dalam Mewujudkan Kawasan Perkotaan Ramah Lingkungan (Eco City) di Makassar

yang meliputi pemangkasan, pemupukan dan pembersihan gulma hanya dilakukan sampai umur tanaman mencapai 3 tahun dan selebihnya tanaman dibiarkan tumbuh secara alami.

Pemanenan pohon yang dilakukan oleh sebagian besar responden adalah sistem tebang pilih tergantung dari pesanan pembeli baik jenis maupun ukuran kayu, hal ini dipilih karena diameter pohon yang beragam, dengan intensitas penebangan rata-rata 1 sampai 2 kali dalam setahun. Petani akan menjual pohon yang memiliki diameter pohon yang relatif besar dan meninggalkan pohon dengan diameter kecil sebagai tabungan yang akan datang. Selain itu, terdapat juga beberapa responden yang melakukan tebang butuh yaitu pemanenan dilakukan sesuai dengan kebutuhan keluarga misalnya untuk bahan bangunan rumah, untuk keperluan biaya sekolah anak dan untuk biaya apabila ada hajatan

\section{Pemasaran}

Dari 47 orang responden terdapat 80,9 \% yang melakukan pemasaran kayu dari hutan rakyat melalui pengumpul kayu/tengkulak. Selanjutnya dari para tengkulak rantai pemasarannya ke industri penggergajian, meubel, pedagang kayu maupun kepada konsumen langsung, hal ini disebabkan karena para tengkulak lebih menguasai kondisi peredaran kayu dan lebih aktif dalam mencari pembeli.

Dari segi harga walaupun harga kayu ditingkat petani tergolong murah namun berdasarkan hasil wawancara terhadap responden mereka masih memperoleh keuntungan dari usaha tani hutan rakyat karena pohon-pohon yang dibudidayakan maupun yang tumbuh dengan sendirinya tidak memerlukan input biaya yang besar karena tidak dilakukan budidaya secara intensif seperti tanaman pertanian dan tanaman perkebunan, selain itu terdapat hasil lain dari hutan rakyat yang dapat mereka manfaatkan.

\section{Analisis Strategi}

\section{Faktor Internal}

Berdasarkan hasil wawancara terhadap responden diperoleh evaluasi variable-variabel faktor internal sebagai berikut.

Variabel yang relatif mempunyai skor paling tinggi dari variabel internal kekuatan yaitu potensi lahan yang yang cukup luas dengan skor 0,968 Sedangkan variabel yang mempunyai skor terendah yaitu input modal yang relatif rendah dengan skor 0,666. Faktor internal kekuatan ini merupakan modal untuk 
A. Wisneni : Keberlanjutan Pengembangan Lorong Garden dalam Mewujudkan Kawasan Perkotaan Ramah Lingkungan (Eco City) di Makassar

kelangsungan pengelolaan hutan rakyat di Kabupaten Luwu Utara.

Berdasarkan hasil wawancara terhadap responden diperoleh evaluasi variabel kelemahan mempunyai skor tertinggi adalah variabel petani menjual kayu bentuk pohon berdiri dengan skor 0,214 . Variabel yang mempunyai skor terendah yaitu tingkat pendidikan yang rendah dengan skor 0.094 .

\section{Faktor Eksternal}

Berdasarkan hasil wawancara terhadap responden diperoleh evaluasi variabel-variabel faktor eksternal peluang menunjukkan bahwa variabel yang relatif mempunyai skor paling tinggi adalah ketersediaan pasar untuk kayu yang berasal dari hutan rakyat dengan skor 0,864. Variabel yang mempunyai skor terendah yaitu kelembagaan Kelompok Tani Hutan (KTH) yang sudah terbentuk dengan skor 0,552. Sedangkan faktor eksternal ancaman diketahui bahwa variabel yang relatif mempunyai skor paling tinggi adalah variabel minimnya informasi pasar terkait harga kayu dengan nilai skor 0,302 . Variabel yang mempunyai skor terendah yaitu kurangnya tenaga penyuluh kehutanan dengan skor 0,242.

\section{Analisis Matrik Internal-Eksternal}

Setelah dilakukan evaluasi terhadap faktor-faktor dan eksternal selanjutnya dilakukan pemaduan antara faktor-faktor kekuatan, kelemahan, peluang dan ancaman. Hasil analisis menunjukkan bahwa total skor faktor internal kekuatan adalah sebesar 2,554 dan faktor internal kelemahan sebesar 0,518, sedangkan untuk faktor eksternal peluang 2,028 dan faktor eksternal ancaman 0,792. Berdasarkan nilai-nilai ini diperoleh posisi strategi pengelolaan Hutan Rakyat terletak pada kuadran I dengan nilai koordinat $(2,036 ; 1,236)$,

Strategi pengelolaan hutan rakyat di Kabupaten Luwu Utara berdasarkan hasil analisis matrik internal-eksternal dapat dilakukan dengan cara :

1) Optimalisasi lahan dengan mengembangkan sistem agroforestri untuk meningkatkan produktivitas lahan dan meminimalkan erosi

2) Meningkatkan kapasitas kelembagaan Kelompok Tani Hutan (KTH)

3) Inventarisasi potensi yang ada untuk mengatur penanaman dan produksi dalam rangka menjamin keberlanjutan hutan rakyat

Strategi pertama dilakukan untuk meningkatkan diversifikasi hasil dengan menanam tanaman MPTS (Multipurpose Tree Spesies) sehingga berkonstribusi 
A. Wisneni : Keberlanjutan Pengembangan Lorong Garden dalam Mewujudkan Kawasan Perkotaan Ramah Lingkungan (Eco City) di Makassar

terhadap perekonomian masyarakat secara berkelanjutan dan juga memberikan dampak positif terhadap pelestarian lingkungan. Strategi kedua dilakukan untuk meningkatkan peran kelompok tani hutan dalam pengelolaan hutan rakyat yang bertujuan untuk meningkatkan kesejahteraan masyarakat dan untuk menyediakan bahan baku berupa kayu tanpa meninggalkan azas kelestarian lingkungan. Untuk menjamin kelestarian hasil hutan rakyat diperlukan penguatan kelembagaan pengelolaan hutan rakyat sehingga terbentuk adanya aturan internal yang mengatur sistem pengelolaan dan penebangan yang disepakati oleh setiap anggotanya, selain itu juga memperkuat posisi petani dalam sistem pemasaran khususnya dalam penentuan harga jual kayu hasil hutan rakyat. Strategi ketiga dilakukan untuk mengetahui potensi yang ada baik jumlah luasan maupun jumlah tegakan sebagai bahan penyusunan rencana pengelolaan hutan rakyat dan untuk menjaga keberlanjutan produksi hasil hutan rakyat.

\section{KESIMPULAN DAN SARAN}

\section{Kesimpulan}

Berdasarkan hasil dan pembahasan terhadap strategi Pengelolaan Hutan Rakyat di Kabupaten Luwu Utara maka dapat diambil kesimpulan sebagai berikut:
1. Hutan rakyat yang ada di Kabupaten Luwu Utara adalah hutan rakyat milik sendiri, dengan luas rata-rata lebih dari 1 ha dan sebagian besar petani menerapkan pola tanam agroforestri. Penerapan teknik silvikultur tergantung pada pola tanam yang diterapkan, sistem pemanenan yang banyak dilakukan menggunakan sistem tebang pilih namun pemasaran sangat tergantung kepada pedagang pengumpul/tengkulak.

2. Faktor internal kekuatan yang dominan berperan dalam pengelolaan hutan rakyat berupa : potensi lahan cukup luas, sedangkan faktor yang merupakan kelemahan utama adalah tingkat pendidikan yang rendah.

Faktor eksternal peluang yang dominan berperan adalah ketersediaan pasar untuk kayu dari hutan rakyat, sedangkan faktor yang merupakan ancaman utama yaitu minimnya informasi pasar terkait harga kayu.

3. Strategi pengelolaan hutan rakyat di Luwu Utara sebaiknya dilakuan dengan strategi SO ( Strength - Opportunity) yaitu dengan cara :

Optimalisasi lahan dengan mengembangkan sistem agroforestri untuk meningkatkan produktivitas lahan dengan menanam tanaman MPTS 
A. Wisneni : Keberlanjutan Pengembangan Lorong Garden dalam Mewujudkan Kawasan Perkotaan Ramah Lingkungan (Eco City) di Makassar

\begin{tabular}{llll}
\hline \hline (Multipurpose Tree Species) dan & memberikan & kebijakan yang \\
sekaligus meminimalkan erosi, & mendukung seperti perluasan \\
(b) Meningkatkan kapasitas & informasi tentang pemasaran hasil \\
kelembagaan Kelompok Tani Hutan & hutan rakyat yang dihasilkan oleh \\
(KTH), (c) Inventarisasi potensi yang & petani.
\end{tabular}
ada untuk mengatur penanaman dan produksi dalam rangka menjamin keberlanjutan hutan rakyat.

\section{DAFTAR PUSTAKA}

Awang, S.A., 2005. Petani, Ekonomi dan Konservasi, Aspek Penelitian dan Gagasan. Pustaka Hutan

\section{Saran}

1. Pengelolaan hutan rakyat di Rakyat. Press Debut, Yogyakarta. Kabupaten Luwu Utara sebaiknya di awali dengan inventarisasi potensi luas dan potensi tegakan berbasis kelompok tani hutan.

2. Peningkatan kapasitas kelembagaan Kelompok Tani Hutan perlu ditingkatkan melalui kegiatan penyuluhan dan pelatihan-pelatihan.

3. Pemerintah perlu mendorong Hardjanto, 2003. Keragaan dan Pengembangan Usaha Kayu Rakyat di Pulau Jawa. Disertasi Program Pasca Sarjana IPB Bogor.

Rangkuti, F., 2002. Analisis SWOT Teknik Membedah Kasus Bisnis. PT.Gramedia Pusaka Utama. Jakarta.

Suprapto, Edi. 2010. Hutan Rakyat : Aspek Produksi, Ekologi dan Kelembagaan. Jurnal Pendidikan. http://arupa.or.id/hutan - rakyat-2. Diaksess tanggal 15 Januari 2020. pengembangan hutan rakyat dengan 